Supporting Information

\title{
“Fingertip"-Guided Noncovalent Functionalization of Carbon Nanotubes by Dendrons
}

\author{
By Sungwook Woo, Yoonmi Lee, Vijaya Sunkara, Ravi Kumar Cheedarala, Hyeon Suk Shin, Hee Cheul Choi*, and Joon Won Park* \\ Department of Chemistry, Pohang University of Science and Technology (POSTECH),
}

San 31, Hyoja-Dong, Nam-Gu, Pohang, Korea 790-784

\section{Experimental Details}

(1) Preparation of dendron 1 (9-anthrylmethyl $N-(\{t r i s[(2-\{[$ tris $(\{2[($ benzyl

amino)carbonyl]ethoxy\}methyl)methylamino]carbonyl\}ethoxy)methyl]methylamino\}carbon

yl)propylcarbamate): $0.50 \mathrm{~g}(0.31 \mathrm{mmol})$ of dendron 2 (9-anthrylmethyl $\mathrm{N}-(\{[\operatorname{tris}(\{2-$

$[(\{$ tris$[(2-$ carboxyethoxy $)$ methyl $]$ methyl $\}$ amino $)$ carbonyl $]$ ethoxy $\}$ methyl $)$ methyl $]$ amino $\}$

carbonyl)propylcarbamate, $\mathrm{Mw}=1614.6)$ was dissolved in DMF (2.0 ml, Sigma-Aldrich)

and a solution of $0.96 \mathrm{~g}$ (ca. 15 equiv) of N,N'-dicyclohexylcarbodiimide (DCC, Aldrich), $0.49 \mathrm{mg}$ (ca. 9.5 equiv) of 1-hydroxybenzotriazole (HOBt, Aldrich) in dichloromethane (20

ml, Sigma-Aldrich) was added. After stirring under nitrogen at room temperature for 10 min, $0.32 \mathrm{ml}$ (ca. 9.5 equiv) of benzylamine (Sigma-Aldrich) was added. After stirring for

$24 \mathrm{~h}$, dichloromethane and DMF were evaporated. The crude product was dissolved in 100 ml of ethyl acetate (J.T.Baker, HPLC grade) and the solution was washed with $10 \%$ hydrochloric acid and brine. After drying with anhydrous $\mathrm{MgSO}_{4}$, filtration, and evaporation, the crude product was loaded in a column packed with silica gel. Column chromatographic purification (eluent: ethyl acetate:methanol $=20: 1(\mathrm{v} / \mathrm{v})$ ) resulted in a yellow solid, and the final weight was $0.37 \mathrm{~g}($ Yield $=50 \%)$.

${ }^{1} \mathrm{H}$ NMR(CDCl $\left.3,300 \mathrm{MHz}\right): \delta 8.46\left(\mathrm{~s}, \mathrm{C}_{14} \mathrm{H}_{9} \mathrm{CH}_{2}, 1 \mathrm{H}\right), 8.30\left(\mathrm{~d}, \mathrm{C}_{14} \mathrm{H}_{9} \mathrm{CH}_{2}, 2 \mathrm{H}\right), 7.99(\mathrm{~d}$, $\left.\mathrm{C}_{14} \mathrm{H}_{9} \mathrm{CH}_{2}, 2 \mathrm{H}\right), 7.49\left(\mathrm{~m}, \mathrm{C}_{14} \mathrm{H}_{9} \mathrm{CH}_{2}, 4 \mathrm{H}\right), 7.33-7.17\left(\mathrm{~m}, \mathrm{CH}_{2} \mathrm{C}_{6} H_{5}, 45 \mathrm{H}\right), 6.67$ (s, 
$\left.\mathrm{CH}_{2} \mathrm{CH}_{2} \mathrm{CH}_{2} \mathrm{CONHC}, 1 \mathrm{H}\right), 6.49$ (t, OCONHCH $\left.\mathrm{CH}_{2}, 1 \mathrm{H}\right), 6.36$ (t, $\mathrm{OCH}_{2} \mathrm{CH}_{2} \mathrm{CONHCH}_{2}, 9 \mathrm{H}$ ), $6.02\left(\mathrm{~s}, \mathrm{C}_{14} \mathrm{H}_{9} \mathrm{CH}_{2} \mathrm{O}, 2 \mathrm{H}\right), 5.85\left(\mathrm{~s}, \mathrm{OCH}_{2} \mathrm{CH}_{2} \mathrm{CONHC}, 3 \mathrm{H}\right), 4.34\left(\mathrm{~d}, \mathrm{NHCH}_{2} \mathrm{C}_{6} \mathrm{H}_{5}, 18 \mathrm{H}\right)$, 3.75-3.51 (m, $\left.\mathrm{CH}_{2} \mathrm{OCH}_{2} \mathrm{CH}_{2} \mathrm{CONH}, 48 \mathrm{H}\right), 3.10$ (q, $\left.\mathrm{NHCH}_{2} \mathrm{CH}_{2}, 2 \mathrm{H}\right), 2.32$ (t, $\mathrm{OCH}_{2} \mathrm{CH}_{2} \mathrm{CONH}, 24 \mathrm{H}$ ), 2.18 (t, $\mathrm{CH}_{2} \mathrm{CH}_{2} \mathrm{CH}_{2} \mathrm{CONH}, 2 \mathrm{H}$ ), 1.99-1.88 (m, $\mathrm{CH}_{2} \mathrm{CH}_{2} \mathrm{CH}_{2}, 2 \mathrm{H}$ ). ${ }^{13} \mathrm{C} \mathrm{NMR}\left(\mathrm{CDCl}_{3}, 300 \mathrm{MHz}\right): \delta 172.2\left(\mathrm{CH}_{2} \mathrm{CH}_{2} \mathrm{CONH}\right), 157.2(\mathrm{OCONH}), 140.4$ $\left(\mathrm{CH}_{2} \mathrm{C}_{6} \mathrm{H}_{5}\right), 138.1\left(\mathrm{C}_{14} \mathrm{H}_{9} \mathrm{CH}_{2}\right), 129.8\left(C_{14} \mathrm{H}_{9} \mathrm{CH}_{2}\right), 128.5\left(\mathrm{CH}_{2} \mathrm{C}_{6} \mathrm{H}_{5}\right), 128.4\left(C_{14} \mathrm{H}_{9} \mathrm{CH}_{2}\right)$, 127.6 $\left(\mathrm{CH}_{2} \mathrm{C}_{6} \mathrm{H}_{5}\right), 127.5\left(\mathrm{CH}_{2} \mathrm{C}_{6} \mathrm{H}_{5}\right), 127.3\left(\mathrm{C}_{14} \mathrm{H}_{9} \mathrm{CH}_{2}\right), 126.6\left(C_{14} \mathrm{H}_{9} \mathrm{CH}_{2}\right), 126.3$ $\left(\mathrm{C}_{14} \mathrm{H}_{9} \mathrm{CH}_{2}\right), 125.9\left(\mathrm{C}_{14} \mathrm{H}_{9} \mathrm{CH}_{2}\right), 69.6\left(\mathrm{NHCCH}_{2} \mathrm{O}\right), 69.4\left(\mathrm{NHCCH}_{2} \mathrm{O}\right), 67.2$ $\left(\mathrm{OCH}_{2} \mathrm{CH}_{2} \mathrm{CONH}\right), 59.7\left(\mathrm{C}_{14} \mathrm{H}_{9} \mathrm{CH}_{2}\right), 59.2\left(\mathrm{NHCCH}_{2}\right), 43.5\left(\mathrm{CH}_{2} \mathrm{C}_{6} \mathrm{H}_{5}\right), 40.1$ $\left(\mathrm{NHCH}_{2} \mathrm{CH}_{2}\right), 36.3\left(\mathrm{OCH}_{2} \mathrm{CH}_{2}\right), 33.9\left(\mathrm{CH}_{2} \mathrm{CH}_{2} \mathrm{CH}_{2}\right), 25.7\left(\mathrm{CH}_{2} \mathrm{CH}_{2} \mathrm{CH}_{2}\right)$. MALDI-TOF MS: $\mathrm{m} / \mathrm{z}=2438.2[\mathrm{M}+\mathrm{Na}]^{+}$(exact mass: $\mathrm{M}=2415.2$ ).

(2) Functionalization of wafer-bound CNTs by dendrons: Substrates were immersed in a $0.20 \mathrm{mM} \mathrm{N}, \mathrm{N}$-dimethylformamide (DMF) solution of each type of the dendrons for $13 \mathrm{~h}$, followed by rinsing with DMF for 1 min, sonication in DMF, deionized water and methanol each for $30 \mathrm{sec}$, rinsing with methanol for $1 \mathrm{~min}$, and drying with $\mathrm{N}_{2}$ stream.

(3) Deprotection of the immobilized dendrons: The substrates were immersed into a dichloromethane solution of $1.0 \mathrm{M}$ trifluoroacetic acid (TFA). After $3 \mathrm{~h}$, they were transferred into a dichloromethane solution of $20 \%(\mathrm{v} / \mathrm{v})$ diisopropylethylamine (DIPEA) and left for $10 \mathrm{~min}$. The substrates were then sonicated in dichloromethane and methanol each for $30 \mathrm{sec}$, in fresh methanol again for $30 \mathrm{sec}$, rinsed with methanol for $1 \mathrm{~min}$, and dried with $\mathrm{N}_{2}$ stream.

(4) Treatment with Tween 20: The substrates were soaked in a $1 \%(\mathrm{v} / \mathrm{v})$ solution of Tween20 in a 50:50 mixture of deionized water and DMF for $3 \mathrm{~h}$. The substrates were then 
sonicated in deionized water, dichloromethane, and methanol each for $30 \mathrm{sec}$, rinsed with methanol for 1 min, and dried with $\mathrm{N}_{2}$ stream.

(5) N,N'-disuccinimidyl carbonate (DSC, Sigma-Aldrich) linker reaction: The substrates were placed in an acetonitrile solution of DSC $(25 \mathrm{mM})$ and diisopropylethylamine (DIPEA, $1 \mathrm{mM}$ ) for $4 \mathrm{~h}$ under $\mathrm{N}_{2}$ atmosphere. The substrates were then washed with DMF for $1 \mathrm{~min}$ and methanol for $30 \mathrm{sec}$, and dried with $\mathrm{N}_{2}$ stream.

(6) Applying gold nanoparticles: $\mathrm{A} \mathrm{NaHCO}_{3}(20 \mu \mathrm{l}, 50 \mathrm{mM}$, pH 8.5, $10 \%$ dimethyl surfoxide (DMSO)) solution of gold nanoparticles $(6 \mu \mathrm{M})$ was dropped onto each substrate kept in a saturated humidity chamber, and $8 \mathrm{~h}$ was allowed for the reaction. The substrates were washed with deionized water and DMSO each for $1 \mathrm{~min}$, then placed in stirred DMSO for $2 \mathrm{~h}$, rinsed with DMSO and methanol each for $1 \mathrm{~min}$, and dried with $\mathrm{N}_{2}$ stream.

(7) Counting the number and the height of gold nanoparticles: In a typical analysis, 3-4 different spots of $5 \mu \mathrm{m} \times 5 \mu \mathrm{m}$ area were scanned with AFM for a sample, and several tubes that appear in the area were investigated. Images of $1 \mu \mathrm{m} \times 1 \mu \mathrm{m}$ or often $500 \mathrm{~nm} \times$ $500 \mathrm{~nm}$ along each tube were subsequently obtained and used for counting the number. The analysis was carried out for multiple samples from independent batches. The numbers of particles used for the spacing analyses were 68 and 84 for dendron $\mathbf{1}$ and $\mathbf{2}$, respectively. Heights of nine vertically standing particles were taken to obtain the average height value. Because measuring the height of particles at the specific orientation (such as point B in Figure 2) is desirable, a limited number of particles were taken into the calculation.

(8) Dispersion experiments: A bath sonicator (Branson 3510) was used for sonication and centrifugation was performed at 2,000 rpm. 
(9) MicroRaman spectra: Raman spectra were measured for the CNTs bound to $\mathrm{Si} / \mathrm{SiO}_{2}$ wafers with Renishaw Raman system 3000 using Ar ion laser (514.5 nm) as an excitation source.

(10) Immobilization of streptavidin: After the same steps for the gold nanoparticle attachment were followed up to the DSC linker reaction, $20 \mu \mathrm{l}$ of $\mathrm{NaHCO}_{3}$ solution (50 $\mathrm{mM}, \mathrm{pH}$ 8.0) dissolving (+)-biotinyl-3,6-dioxaoctanediamine (EZ-Link® Biotin-PEOAmine, Pierce; $0.5 \mathrm{mg} / \mathrm{ml}$ ) was placed on top of a substrate, and subsequently $3 \mathrm{~h}$ at room temperature was allowed for the reaction between the NHS group and the amine group of the biotin. After washing with deionized water briefly and drying with a stream of nitrogen, the treated substrate was placed in $20 \mu \mathrm{l}$ of $\mathrm{NaHCO}_{3}$ solution $(50 \mathrm{mM}$, pH 8.0) dissolving ethanolamine $(0.5 \% \mathrm{v} / \mathrm{v})$. Three hours were allowed at room temperature to quench the remained NHS group. Subsequently, brief washing of the resulting substrate with DMF was followed. Finally, a phosphate buffer saline solution $(20 \mu \mathrm{l}, 10 \mathrm{mM}, \mathrm{pH} 7.4)$ dissolving streptavidin (Sigma-Aldrich; $0.010 \mathrm{mg} / \mathrm{ml}$ ) was placed on top of the substrate, and $30 \mathrm{~min}$ was allowed at room temperature. The substrate was placed in deionized water with stirring for $1 \mathrm{~h}$, and dried with $\mathrm{N}_{2}$ stream.

\section{Supporting Figures}




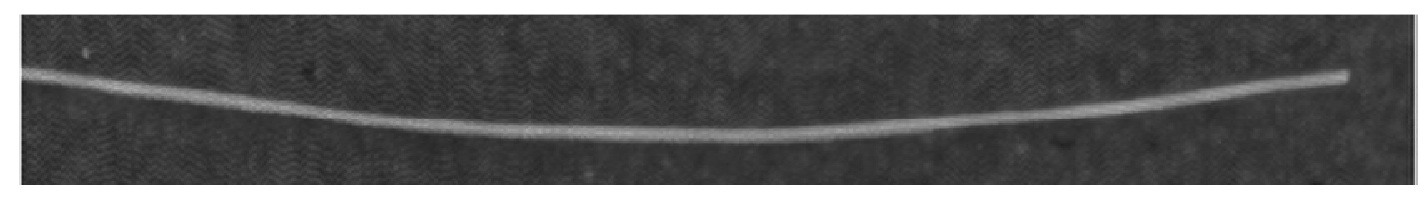

\section{$200 \mathrm{~nm}$}

Figure S1. Tapping mode AFM images of a CNT obtained before (top) and after (bottom) the treatment of $\mathbf{1}$.

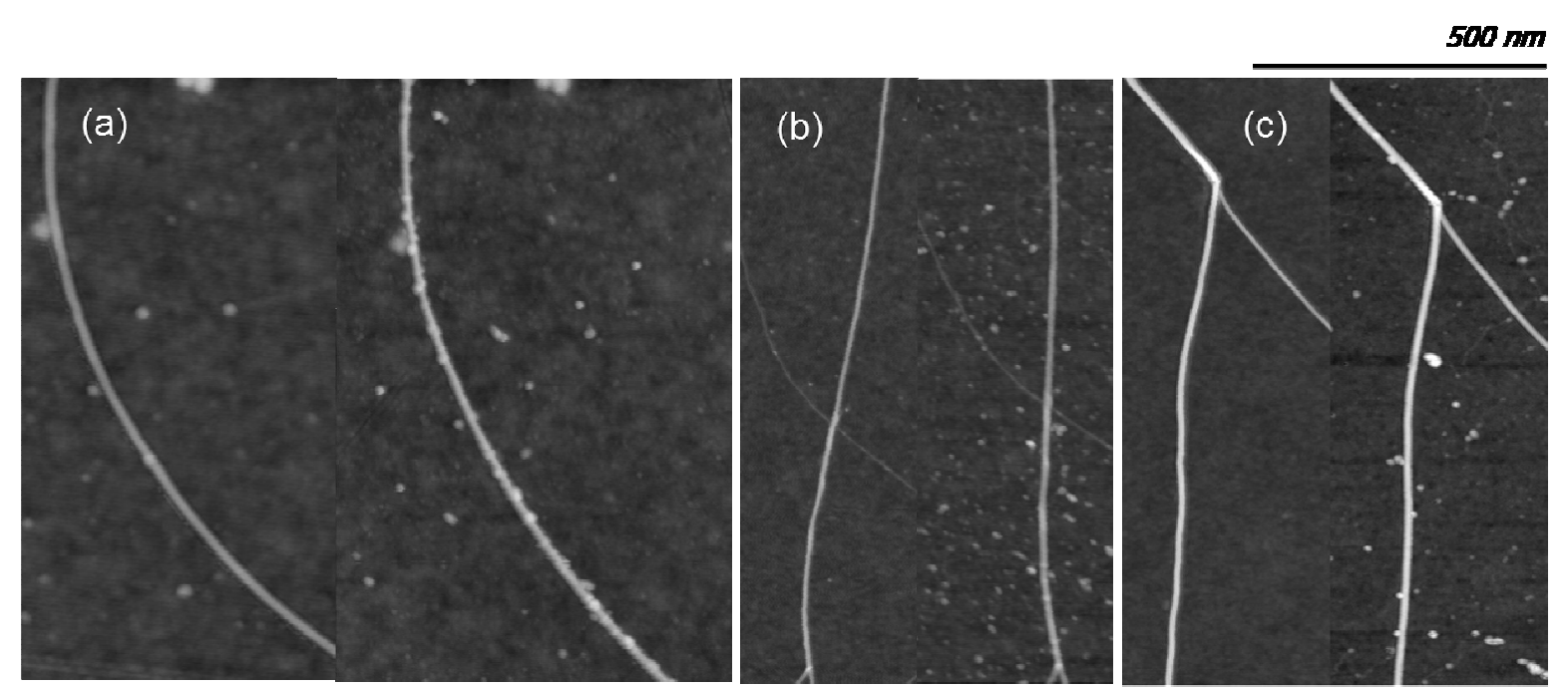

Figure S2. AFM images obtained before and after applying gold nanoparticles to (a) CNTs

functionalized with the dendron 1, (b) bare CNTs, and (c) Tween20-treated CNTs. There is no observable binding in cases of (b) and (c). 

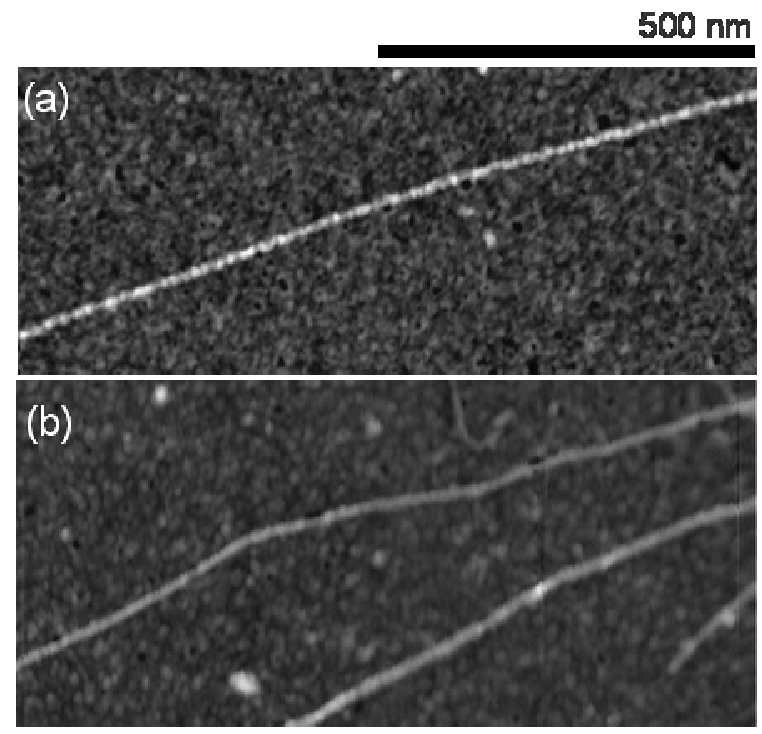

Figure S3. Control experiments with streptavidin on (a) bare CNTs and (b) Tween20coated CNTs. (a) The image shows considerable nonspecific binding of streptavidin onto CNTs. (b) The image reveals that Tween20 repels streptavidin.

\section{A control test with t-Boc protected dendron 1 analog}

A dendron containing a t-Boc moiety as the protecting group instead of the anthryl group was tested to investigate the influence of the latter protecting group on the binding event. While the anthryl group might interact with CNTs through $\pi-\pi$ interaction, the t-Boc group is not the case. A dendron having the same terminal groups as those of dendron $\mathbf{1}$ and a $\mathrm{t}$ Boc group as the protecting group (Figure S4a) was employed for this investigation, and showed a similar binding probability or density (18.1 particles $/ \mu \mathrm{m})$. 

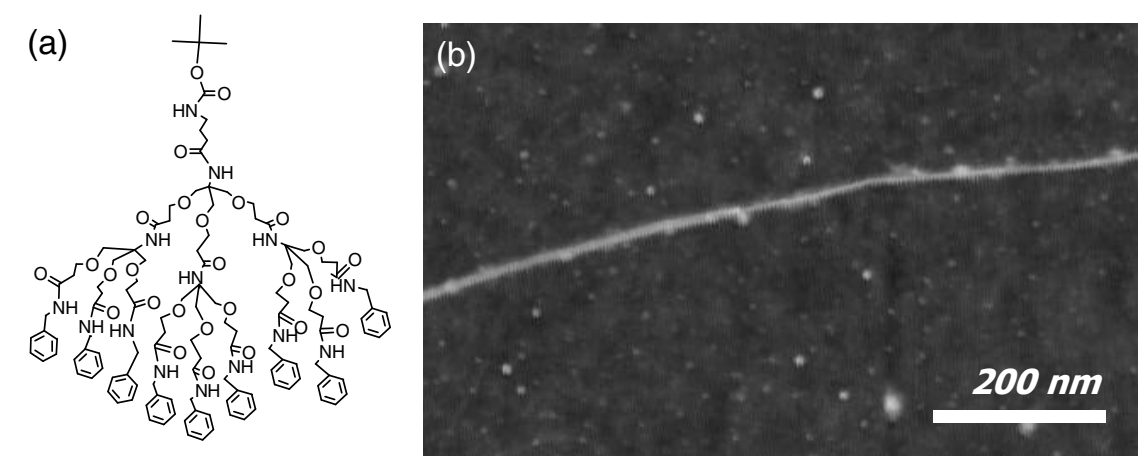

Figure S4. (a) t-Boc protected dendron 1 analog (1'). (b) The dendron 1' showed a similar binding affinity toward the sidewalls of CNTs.

3.1. The procedures for the immobilization of dendron 1' on CNTs were the same as those for dendron 1.

3.2. NMR and mass spectral data of dendron 1'

${ }^{1} \mathrm{H} \mathrm{NMR}\left(\mathrm{CDCl}_{3}, 300 \mathrm{MHz}\right)$

$\delta \quad 7.28-7.23 \quad\left(\mathrm{~m}, \quad \mathrm{CH}_{2} \mathrm{C}_{6} \mathrm{H}_{5}, \quad 45 \mathrm{H}\right), \quad 7.21-7.18 \quad\left(\mathrm{~s}, \quad \mathrm{NHCH}_{2} \mathrm{C}_{6} \mathrm{H}_{5}, \quad 9 \mathrm{H}\right), \quad 6.83 \quad(\mathrm{~s}$, $\left.\mathrm{CH}_{2} \mathrm{CH}_{2} \mathrm{CH}_{2} \mathrm{CONHC}, 1 \mathrm{H}\right), 6.64\left(\mathrm{~s}, \mathrm{OCH}_{2} \mathrm{CH}_{2} \mathrm{CONHC}, 3 \mathrm{H}\right), 6.08\left(\mathrm{~s},\left(\mathrm{CH}_{3}\right)_{3} \mathrm{OCONH}, 1 \mathrm{H}\right)$, 4.34 (d, $\left.\mathrm{NHCH}_{2} \mathrm{C}_{6} \mathrm{H}_{5}, 18 \mathrm{H}\right), \quad 3.65-3.52$ (m, $\left.\mathrm{CH}_{2} \mathrm{OCH}_{2} \mathrm{CH}_{2} \mathrm{CONH}, \quad 48 \mathrm{H}\right), \quad 3.01$ (q, $\left.\mathrm{NHCH}_{2} \mathrm{CH}_{2}, 2 \mathrm{H}\right), 2.40-2.35\left(\mathrm{t}, \mathrm{OCH}_{2} \mathrm{CH}_{2} \mathrm{CONH}, 18 \mathrm{H}\right), 2.20-2.18\left(\mathrm{t}, \mathrm{OCH}_{2} \mathrm{CH}_{2} \mathrm{CONH}\right.$, 6H), 2.11 (t, $\left.\mathrm{CH}_{2} \mathrm{CH}_{2} \mathrm{CH}_{2} \mathrm{CONH}, 2 \mathrm{H}\right), 1.63\left(\mathrm{~m}, \mathrm{CH}_{2} \mathrm{CH}_{2} \mathrm{CH}_{2}, 2 \mathrm{H}\right), 1.41\left(\mathrm{~s},\left(\mathrm{CH}_{3}\right)_{3}, 9 \mathrm{H}\right)$.

${ }^{13} \mathrm{C} \mathrm{NMR}\left(\mathrm{CDCl}_{3}, 300 \mathrm{MHz}\right)$

$\delta 171.4\left(\mathrm{CH}_{2} \mathrm{CH}_{2} \mathrm{CONH}\right), 171.2(\mathrm{OCONH}), 138.5\left(\mathrm{CH}_{2} \mathrm{C}_{6} \mathrm{H}_{5}\right), 128.6-127.3\left(\mathrm{CH}_{2} \mathrm{C}_{6} \mathrm{H}_{5}\right)$, $69.4\left(\mathrm{NHCCH}_{2} \mathrm{O}\right), 69.2\left(\mathrm{NHCCH}_{2} \mathrm{O}\right), 67.3\left(\mathrm{OCH}_{2} \mathrm{CH}_{2} \mathrm{CONH}\right), 59.2\left(\mathrm{NHCCH}_{2}\right), 43.4$ $\left(\mathrm{CH}_{2} \mathrm{C}_{6} \mathrm{H}_{5}\right), 36.4\left(\mathrm{OCH}_{2} \mathrm{CH} 2\right), 28.4\left(\left(\mathrm{CH}_{3}\right)_{3}\right)$.

MALDI-TOF MS: m/z = 2304.2 $[\mathrm{M}+\mathrm{Na}]^{+}$(exact mass: $\mathrm{M}=2281.2$ ). 